\title{
Infection of gastrointestinal parasites among slaughtered cattle (Bos taurus) in Modern Abattoir, Minna, Niger State
}

\author{
Eke, S. S. ${ }^{1 *}$, Kamaldeen, I. K. ${ }^{2}$, Omalu, I. C. J. ${ }^{2}$, Nwokocha, F. A. ${ }^{2}$, Otuu, C. A. ${ }^{3}$, Udeh, E. O.4, \\ Ocha, I. M. ${ }^{2}$, Ismail, A. ${ }^{2}$ and Ogunniyi, M. T. ${ }^{2}$ \\ 1Departmentof Biological Sciences, Admiralty University of Nigeria, Ibusa/Ogwashi - Uku, Delta State, Nigeria. \\ ${ }^{2}$ Department of Animal Biology, Federal University of Technology, Minna, Niger State, Nigeria. \\ ${ }^{3}$ Department of Zoology and Environmental Biology, University of Nigeria Nsukka, Enugu State, Nigeria. \\ ${ }^{4}$ Centre for Integrated Health Programs, Wuse 2, FCT Abuja, Nigeria. \\ *Corresponding author. Email: ekesamuel2012@gmail.com
}

Copyright @ 2021 Yakubu et al. This article remains permanently open access under the terms of the Creative Commons Attribution License 4.0, which permits unrestricted use, distribution, and reproduction in any medium, provided the original work is properly cited.

Received 20th March, 2020; Accepted 27th April, 2020

\begin{abstract}
Livestock and their products are the major source of animal protein. They also play a crucial role in the economy of most nations including Nigeria. In Nigeria, animals are mostly managed by extensive system and this predisposes them to gastrointestinal parasites. This study is aimed at determining the prevalence of gastrointestinal parasites of cattle slaughtered in Minna Abattoir. A total of two hundred and seventeen (217) faecal samples were collected and analyzed for the presence of gastrointestinal parasites using saturated sodium chloride flotation and sedimentation techniques. An overall prevalence rate of $169(77.88 \%)$ of gastrointestinal parasites were recorded. Among the selected cattle breeds sampled, a prevalence rate of $114(67.45 \%)$ for white Fulani, 30 (17.75\%) for Sokoto Gudali and 25 (14.79\%) for red Bororo were obtained. Seven (7) gastrointestinal parasites detected were Strongyloides spp, Trichuris spp, Haemonchus spp, Eimeria spp, Taenia spp, Moniezia spp and Fasciola spp. Haemonchus spp had the highest rate of infection $69(40.82 \%)$ followed by Strongyloides spp $22(13.04 \%)$ while the one with the least prevalence was Eimeria spp $12(7.10 \%)$. It was observed that female ruminants were more infected $(53.84 \%)$ than their male counterpart $(46.15 \%)$. The older also had higher infection rate $(50.29 \%)$ than the younger ones $(49.72 \%)$. There was no significant difference $(p>0.05)$ on the infection rate in relation to gender and age. It is paramount to use appropriate management systems and rational use of drugs to solve this health problem.
\end{abstract}

Keywords: Bos taurus, gastrointestinal, red Bororo, Sokoto Gudali, white Fulani.

\section{INTRODUCTION}

Nigeria had an estimated cattle population of 13.9 million as at 1990 of which 11.5 million of this population were kept under pastoral system and 2.4 million in the villages (Okoli et al., 2012). In Nigeria, the livestock sector contributes $5.2 \%$ of the gross domestic products (GDP) while cattle production solely contributes $50 \%$ of the total meat (Adedipe et al., 2014). Essentially, there is high demand for these ruminants not only for food but also for religious and social ceremonies and represent a valuable asset in both traditional and modern agriculture; in addition, they also provide meat, milk, skin, and draught power for farming (Tewe et al., 1997). In some traditional settings, they also play an essential role in the socioeconomic system, representing family wealth or they can be regarded as a survival kit by nomadic people. Cattle are slaughtered at virtually all abattoirs in Nigeria where they are sold to the public as beef (Edosomwan and Shoyemi, 2012). Meat is one of the most important livestock products. The quantity of meat and revenue generated from domestic livestock is far below the national demand due to factors such as death and ill health with associated reduced productivity and increased cost of 
treatment (Bolajoko et al., 2011).

Helminths however, are known to be a major setback to ruminant's well-being and productive performance (Hesterberg et al., 2008). Infections with helminthes parasites especially those of gastrointestinal tract (GIT) can cause substantial losses to cattle owners. According to (Loukopoulos et al., 2007), a parasite is an undesirable organism that exists in or on the body of another living organism or host. These parasites cause a gradual deterioration of animal performance and have been known to be major economic losses in the tropics and in Nigeria (Kudi et al., 2009). The effect of the disease ranges from decreased utilization of feeds in unthrifty animals to weights loss or even death (Anon et al., 2005). Symptoms include loss of weight, poor growth, unthriftiness and a marked decreased in milk production, gut damage, blood loss, and anemia. Other losses include decrease in protein production in terms of quantity and quality of milk, meat, dairy product, wool and damage to hide and skin. Among the gastrointestinal parasites, nematodes present the greatest potential problems of which barber pole worm (Haemonchus spp) is the most important (Ademola and Eloff, 2010). Gastrointestinal helminths are well spread in Nigeria (Ademola and Eloff, 2010) and are known to cause disease in ruminants which are of great economic importance. In Nigeria, the prevalence of helminthosis varies from place to place and shows seasonal fluctuations (Ademola and Eloff, 2010). The understanding of dynamics of infection could aid management of helminthosis.

The trematodes, cestodes and protozoans are also important parasites that affect ruminant livestock. Some of these are zoonotic and therefore pose a threat to public health (Kagira et al., 2001). Abattoirs are instruments for the insurance of wholesome meat and meat products as well as providing abattoir byproducts for livestock base industries. More importantly, abattoirs are used for the purpose of surveillance against animal and zoonotic diseases. The importance of abattoir records in analysis of prevalence rate and planning strategy for the control of livestock diseases cannot be undermined (Awah Ndukum et al., 2010). Therefore, this study aimed at determining the prevalence of gastrointestinal parasite in cattle slaughtered at the Minna Modern Abattoir, Niger State.

\section{MATERIALS AND METHODS}

\section{Ethical approval}

The research was conducted after an approval from the Niger State Veterinary Hospital, Minna, Niger State.

\section{Study area}

The study was carried out between July to September,
2019 in Minna modern abattoir located at Tayi village, Bosso, Minna, Niger State, Nigeria. The study area (99 $30^{\prime} 0.8^{\prime \prime} \mathrm{N}, 632^{\prime} 46.74 " \mathrm{E}$ ) is found at an altitude of 259.14 $\mathrm{m}$. The average annual temperature is $27.5^{\circ} \mathrm{C}$. The least amount of rainfall occurs in January. Most of the precipitation in Minna falls in September, averaging 260 $\mathrm{mm}$. The temperature is highest on average in March, at around $30.5^{\circ} \mathrm{C}$. August is the coldest month, with temperature averaging $25.3^{\circ} \mathrm{C}$ (Eke et al., 2019). The variation in the precipitation between the driest and wettest month is $259 \mathrm{~mm}$, according to (Eke et al., 2019).

\section{Sample collection}

Systematic random sampling method was employed in selecting the examined cattle during the study. The samples were identified and labelled as male or female, and other records such as age and breed were taken (Cheesbrough, 2005).

\section{Sample population}

A total of 217 fresh faecal samples were collected (directly from the rectum of the slaughtered cattle, one sample per animal) using a pair of sterile hand gloves into a sterile sample bottle. About 10 grams of the faecal samples were collected per cattle. The samples were taken to the Parasitology Laboratory Unit of Animal Biology Laboratory, Federal University of Technology Minna, Niger state for parasitological analysis and identification.

\section{Parasitological examination}

Faecal samples were examined by flotation and sedimentation techniques for the presence of gastrointestinal parasites. The faecal samples were dissolved in saturated salt solution in a test tube. The obtained faecal solutions were filtered using sieve with minute holes. This was done so as to trap the large particles or debris. The filtrate was turned into a sample bottle and covered with cover slip for 10 to 15 minutes. It was then mounted and examined under the microscope using objective of $\mathrm{X} 10$ to determine the presence of eggs (ova) and objective X40 to determine themorphological structure of the ova of the helminthes seen. This method was used to examine all samples collected (Cheesbrough, 2005).

\section{Data analysis}

Data were subjected to descriptive statistical analysis using percentages and Chi - square analysis was used in determining the prevalence rates in the different helminth parasites in relation to sex, breed, and age. $p<0.05$ was considered indicative of a statistically significant difference 
Table 1. Parasite of cattle slaughtered at Minna abattoir.

\begin{tabular}{lcccc}
\hline $\begin{array}{l}\text { Gastrointestinal } \\
\text { parasites }\end{array}$ & Sokoto Gudali $(\mathbf{n}=\mathbf{3 9})$ & White Fulani $(\mathbf{n}=\mathbf{1 3 4})$ & Red Bororo $(\mathbf{n}=\mathbf{4 4})$ & Total $(\mathbf{n}=\mathbf{2 1 7})$ \\
\cline { 2 - 5 } Trematode & No $+\mathrm{ve}(\%)$ & No $+\mathrm{ve}(\%)$ & No +ve $(\%)$ & No +ve $(\%)$ \\
Fasciola spp & $4(20.00)$ & $13(65.00)$ & $3(15.0)$ & $20(11.83)$ \\
& & & & \\
Cestode & $4(21.05)$ & $12(63.15)$ & $3(15.78)$ & $19(11.24)$ \\
Taeniids & $2(15.38)$ & $8(61.53)$ & $3(28.07)$ & $13(7.69)$ \\
Moniezia spp & & & & \\
Nematode & $11(15.94)$ & $49(71.01)$ & $9(13.04)$ & $69(40.82)$ \\
Haemonchus spp & $3(21.42)$ & $9(64.28)$ & $2(14.28)$ & $14(8.28)$ \\
Trichuris spp & $4(18.18)$ & $15(68.18)$ & $3(13.63)$ & $19(13.01)$ \\
Strongloides spp & & & & \\
Protozoan & $2(16.67)$ & $8(6.67)$ & $2(16.67)$ & $12(7.10)$ \\
Eimeria spp & $30(17.75)$ & $114(67.45)$ & $25(14.79)$ & $169(77.88)$ \\
Total & & & & \\
\hline
\end{tabular}

$X^{2} \mathrm{cal}=1.55 ; \mathrm{X}^{2} \mathrm{tab}=21.03 ; \mathrm{df}=1$.

\section{RESULTS}

\section{Overall Prevalence of Gastrointestinal parasites encountered}

Seven (7) parasites of various genera were encountered in the samples examined. These include; Strongyloides spp, Trichuris spp, Haemonchus spp, Eimeria spp, Taeniids, Moniezia spp and Fasciola spp. Haemonchus spp. was the most prevalent $69(40.82 \%)$ intestinal parasite encountered followed by Strongyloides spp. 22 (13.01\%), Fasciola spp. 20 (11.83\%), Taeniids 19 (11.24\%), Trichuris spp. 14 (8.28\%), Moniezia spp. 13 (7.69\%), while Eimeria spp. 12 (7.10\%) were the least prevalent parasites encountered.

These results showed that nematode was the most prevalent with $(62.11 \%)$, followed by cestode species $(18.93 \%)$, trematodes $(11.83 \%)$ and protozoan $(7.10 \%)$ (Table1). The prevalence of these gastrointestinal parasites are not significantly different.

\section{Gender and age prevalence of gastrointestinal parasites of the cattle}

Based on sex, the females had the highest infection 91 $(53.84 \%)$ than their male counterparts $78(46.15 \%)$ of gastrointestinal parasites. There was no significant difference $(p=5.99)$ on the infection rate in relation to gender.

The comparison of the prevalence of infection between age groups of the animals showed that 3.5 to 4 years $(39.05 \%)$ animals were more frequently infected followed by those of ages 2.5 to 3 years with (37.86\%), while 2 to 2.5 years had (11.83\%) prevalence and 4.5 to 5 years were the least infected with (11.24\%) (Table 2). There was no significant difference $(p=5.99)$ on the infection rate in relation to age.

\section{Prevalence of gastrointestinal parasites in relation to breed}

Out of the 169 infected cattle white Fulani was the most affected with 114 cases, with single and mixed infections of $(67.54 \%)$ and $(32.45 \%)$ respectively, followed by Sokoto Gudali with 30 infected individuals, single (73.33\%) and (26.66\%) mixed infections respectively and red Bororo having the least infected individuals 25 , single $(56.00 \%)$ and mixed infections of $(44.00 \%)$ (Table 3 ).

\section{DISCUSSION}

The result of the present study clearly indicates that cattle slaughtered from the Modern Minna Abattoir were infected with different strains of gastrointestinal parasites including nematodes, cestodes, trematodes and protozoa from the months of July to September 2019. During wet season, there is higher prevalence which could be attributed to the high moisture content and lower temperature which favour the growth and development of larvae on pasture, which in turns favours contact between the host and parasites. Higher parasitic infection during wet season was reported in some studies (Ohaeri et al., 2012).

The findings of this study showed that $77.8 \%$ (169/217) 
Table 2. Prevalence of Gastrointestinal parasites of cattle slaughtered at Minna abattoir.

\begin{tabular}{lcccccccc}
\hline \multirow{2}{*}{ Parameters } & \multicolumn{2}{c}{ Sokoto Gudali $(\mathbf{n}=\mathbf{3 9})$} & \multicolumn{2}{c}{ White Fulani $(\mathbf{n}=\mathbf{1 3 4})$} & \multicolumn{2}{c}{ Red Bororo $(\mathbf{n}=\mathbf{4 4})$} & \multicolumn{2}{c}{ Total $(\mathbf{n}=\mathbf{2 1 7})$} \\
\cline { 2 - 8 } & No Exm & No + ve & No Exm & No + ve & No Exm & No +ve & No Exm & No +ve \\
\hline Sex & & & & & & & & \\
Male & $11(11.22)$ & $9(11.53)$ & $68(69.38)$ & $59(75.64)$ & $19(19.38)$ & $10(12.82)$ & $98(45.16)$ & $78(46.15)$ \\
Female & $28(23.52)$ & $21(23.07)$ & $66(55.46)$ & $55(60.43)$ & $25(21.00)$ & $15(16.48)$ & $119(54.83)$ & $91(53.84)$ \\
Total & $39(17.97)$ & $30(17.75)$ & $134(61.75)$ & $114(67.45)$ & $44(20.27)$ & $25(14.79)$ & $217(100.0)$ & $169(77.88)$ \\
& & & & & & & \\
Age group & & & & & & & \\
$2-2.5 y r s$ & $4(12.50)$ & $2(10.0)$ & $18(56.25)$ & $12(60.00)$ & $10(31.25)$ & $6(30.0)$ & $32(32.74)$ & $20(11.83)$ \\
$2.5-$ 3yrs & $17(21.25)$ & $12(18.75)$ & $44(55.0)$ & $37(57.81)$ & $19(23.75)$ & $15(23.43)$ & $80(36.86)$ & $64(37.86)$ \\
$3.5-$ yyrs & $19(24.64)$ & $17(25.75)$ & $47(61.03)$ & $39(59.09)$ & $11(14.28)$ & $10(15.15)$ & $77(35.48)$ & $66(39.05)$ \\
4.5 - 5yrs & $14(50.00)$ & $9(32.14)$ & $9(32.14)$ & $7(36.84)$ & $5(17.85)$ & $3(15.78)$ & $28(12.91)$ & $19(11.24)$ \\
Total & $54(24.88)$ & $40(23.66)$ & $118(54.37)$ & $95(56.21)$ & $45(20.73)$ & $34(20.11)$ & $217(100)$ & $169(77.88)$ \\
\hline
\end{tabular}

Sex: $\mathrm{X}^{2} \mathrm{cal}=4.97 ; \mathrm{x} 2 \mathrm{tab}=5.99 ; \mathrm{df}=2$. Age: $\mathrm{X}^{2} \mathrm{cal}=10.63 ; \mathrm{x} 2 \mathrm{tab}=12.59 ; \mathrm{df}=6$.

Table 3. Prevalence of gastrointestinal parasites of cattle slaughtered at Minna abattoir in relation to breed.

\begin{tabular}{lccc}
\hline Breed & Single & Mixed & Total \\
\hline Sokoto Gudali & $22(73.33)$ & $8(26.66)$ & $30(17.75)$ \\
White Fulani & $77(67.54)$ & $37(32.45)$ & $114(67.45)$ \\
Red Bororo & $14(56.00)$ & $11(44.00)$ & $25(14.79)$ \\
Total & $113(66.86)$ & $56(33.13)$ & $169(77.88)$ \\
\hline
\end{tabular}

$X^{2} c a l=1.86 ; X^{2}$ tab $=5.99 ; d f=2$.

of the cattle examined were positive for gastrointestinal helminth eggs, thus gives an insight on the burden of helminths among cattle in Minna Modern Abattoir. Nematode (eggs) infections were particularly high, as they accounted for $(62.11 \%)$ of the total helminth burden. High nematode infection has huge impact on livestock production since they result in reduced milk, meat, wool, hide products, and stamina of working animals (Ekong et al., 2012), resulting in the diminution of production potentials such as decreased growth rate, weight loss in young growing calves, and late maturity of the animals (Swai et al., 2006). In this study, cestode recorded $(18.93 \%)$ trematode $(11.83 \%)$ and protozoan infection was the lowest with $(7.10 \%)$. The aforementioned parasites are of significant public health importance. Fasciola gigantica is a liver trematode known to be zoonotic and have caused considerable economic losses and health problems (Fox et al., 2011).

The overall prevalence $77.8 \%$ of helminth infection obtained in this study is similar to that of Olajide et al. (2017), who reported a prevalence of $77.1 \%$ in Akure Abattoirs, Ondo State Nigeria and Bisimwa and Lugano (2018) who reported a prevalence of $74.4 \%$ in Walungu Territory, South Kivu Province, Eastern Democratic Republic of Congo, which were both higher than the 50.8\% and $62.1 \%$ earlier reported in south-eastern and south- southern Nigeria, respectively by Elele et al. (2013) and Nwigwe et al. (2013) but lower than that of $82.2 \%$ reported by Biffa et al. (2007) in Ethiopia. The differences observed could be due to the periods or seasons in which the studies were conducted as well as the sources of cattle sampled in the various regions. Also, poor management of cattle such as poor grazing practices, infrequent transfer of animals from the holding place and watering of animals from natural pool during the rainy season always affected the animals which can invariably give room for high prevalence of intestinal helminths.

Helminths ova identified in this study were similar to those identified by Edosomwan and Shoyemi (2012) and Elele et al. (2013) in earlier studies carried out in Benin and Port Harcourt, south-south Nigeria. Findings from these studies showed that 12 and 16 different helminths were obtained from Benin and Port Harcourt, respectively, and some of the helminths were similar to those found in this study. It can therefore be suggested that the similarity in the helminth profile indicates exposure of these animals to common conditions (e.g., ecology, pasture, and humidity) which are prevalent in northern Nigeria where majority of these animals are sourced from prior to being transported to different, abattoirs in Nigeria. The findings in this study show that Haemonchus spp, Trichuris spp, Strongyloides spp, Fasciola spp, Taeniids, Monezia spp and Eimeria spp 
were observed and could be compare with previous studies in Nigeria. These findings further revealed that Haemonchus species were the most abundant among the helminths with prevalence of $(40.82 \%)$, which is in agreement with the work done of Ademola and Eloff (2010) who recorded higher incidence of Haemonchus contortus infection during rainy season. $H$. contortus is a bloodsucker and can induce anaemia and oedema. The haemolytic protein that the parasite releases could as well lead to other intestinal disturbances. $H$. contortus is also known to adapt well to even harsh conditions which makes it more difficult to eliminate.

In this study, sex of the animal was found to be correlated with the prevalence of the parasites reveals that females are more infected with gastrointestinal parasites than males, which conforms with the study of Bisimwa et al. (2018) who reported that female animals showed higher parasitic infection than males despite similar management practice. This could be attributed to be due to the fact that female animals are more susceptible to infections than male and hence sex is determinant factor in influencing prevalence of parasites. However according to Adedipe et al. (2014) who claimed that both the male and female animals have equal chance of being infected with gastrointestinal helminths. One major factor that would have accounted for this is the fact that both the male and female cattle under the local setting in Nigeria are exposed to poor feeding and veterinary care, factors accountable for equal susceptibility to helminth infections. Though earlier findings by Raza et al. (2013) indicated that the male cattle were more voracious likely to be infected with helminth than the female, reason given was that male animals were more and thus pick up more ova of helminthes on the pasture.

Furthermore, the breed prevalence of this study shows that the white Fulani had the highest prevalence followed by Sokoto Gudali and red Bororo having the least infection which is in conformity but lower with that reported by Adedipe et al. (2014) who recorded the presence of white Fulani, Sokoto Gudali and red Bororo. The difference in the prevalence obtained could be attributed to the existence of favourable environmental factors necessary for the prolonged survival and development of infective larval stage of most helminths (Yuguda et al., 2018).

In respect to age of the animals studied, those within the range of 3 years and 4 years recorded the highest prevalence of gastrointestinal parasite. This finding agrees with the reports of Yuguda et al. (2018) and Ntonifor et al. (2013) which clearly showed that adult animals could have been harbouring matured worms due to prolonged exposure compared to younger animals.

In this study, single infections were found to be more prevalent in comparison to mixed infections in this study. Mixed infection was characterized by the presence of two or more helminths. The phenomenon of mixed infection has been suggested to be an important cause of morbidity and reduced production in livestock (Kumsa et al., 2011). Furthermore, the immune-suppression of the host immune system by mixed infections increases host susceptibility to other diseases or parasites (Wang et al., 2006). Out of 217 samples examined, $113(66.86 \%)$ had single and 56 (33.13\%) had mixed infection with different helminths species. This result showed similarity with that of Yuguda et al. (2018) who reported 167 (55.67\%) as single and 56 $(18.67 \%)$ as mixed infection out of the 300 samples examined.

\section{Conclusion}

The findings in this study show that Haemonchus spp., Trichuris spp., Strongyloides spp., Fasciola spp., Taeniids sp., Monezia spp. and Eimeria spp. are prevalent in the study area. White Fulani is the most predisposed to parasites, females are more predisposed than males, older animals are more predisposed to GIT parasites than young adults cattle. The prevalence of single infestations is higher than mixed. The study was a quantitative and tells whether the parasites are present or not. However, subclinical infections may be very important economically leading to retarded growth; reduced productivity and the animals will also continuously contaminate pastures.

\section{Recommendations}

Cross breed of cattle of resistant breeds and susceptible breeds should be encouraged. Younger animals should be bred for production. There should be appropriate grazing system, rational use of drugs as antiparasitic agents, use of veterinary advice and rotation of drugs, adherence to drug withdrawal periods for meat and milk. However, resistance to these drugs has recently been observed on several occasions. In order to delay the development of drug-resistant parasite strains, anthelmintics must not be overused.

\section{CONFLICT OF INTEREST}

The authors declare that they have no conflict of interest.

\section{REFERENCES}

Adedipe, O. D., Uwalaka, E. C., Akinseye, V. O., Adediran, O. A., \& Cadmus, S. I. B. (2014). Gastrointestinal helminths in slaughtered cattle in Ibadan, South-Western Nigeria. Journal of Veterinary Medicine, Volume 2014, Article ID 923561, 6 pages.

Ademola, I. O., \& Eloff, J. N. (2010). In vitro anthelmintic activity of Combretum molle (R. Br. ex G. Don) (Combretaceae) against Haemonchus contortus ova and larvae. Veterinary Parasitology, 169(1-2), 198-203.

Anon, J. B. (2005). Current management of acute bacterial rhinosinusitis and the role of moxifloxacin. Clinical Infectious Diseases, 41(2), 167-176. 
Awah Ndukum, J., Kudi, A. C., Bradley, G., Ane-Anyangwe, I. N., Fon-Tebug, S., \& Tchoumboue, J. (2010). Prevalence of bovine tuberculosis in abattoirs of the littoral and Western highland regions of cameroon: a cause for public health concern. Veterinary Medicine International, Volume 2010, Article ID 495015, 8 pages.

Bisimwa, N. P., Lugano, R. M., Bwihangane, B. A, Wasso, S. D, Kinimi, E., Banswe, G. (2018). Prevalence of Gastro-Intestinal Helminths in Slaughtered Cattle in Walungu Territory, South Kivu Province, Eastern Democratic Republic of Congo. Austin Journal of Veterinary Science and Animal Husbandry, 5(1), 1039.

Bolajoko, M. B., G. D. Moses, K. O. Gambari-Bolajoko, V. I. Ifende, P. Emenna, \& A. Bala. (2011). Participatory rural appraisal of livestock diseases among the Fulani community of the Barkin Ladi local government area, Journal of Veterinary Medicine and Animal Health, 3(1), 11-13.

Cheesbrough, M. (2005). District laboratory practice for tropical countries. Part 2. Cambridge University Press, UK. p.434.

Edosomwan, E. U., and O. O. Shoyemi. (2012). Prevalence of gastrointestinal helminth parasites of cattle and goats slaughtered at abattoirs in Benin City, Nigeria. African Scientist, 13(2), 109-114.

Eke, S. S., Omalu, I. C. J., Ochaguba, J. E., Urama, A. C., Hassan, S. C., Otuu, C. A., \& Okafor, I. D. (2019). Prevalence of gastrointestinal parasites of sheep and goats slaughtered in Minna Modern Abattoir Niger State, Nigeria. Journal of Animal Science and Veterinary Medicine, 4(2), 65-70.

Ekong, P. S., Juryit, R., Dika, N. M., Nguku, P., \& Musenero, M. (2012). Prevalence and risk factors for zoonotic helminth infection among humans and animals-Jos, Nigeria, 20052009. Pan African Medical Journal, 12(1), 6p.

Elele, K., O. Owhoeli, \& L. B. Gboeloh (2013). Prevalence of species of helminthes parasites in cattle slaughtered in selected abattoirs in Port Harcourt, south-south, Nigeria, International Research on Medical Sciences, 1(2), 10-17.

Fox, N. J., White, P. C., McClean, C. J., Marion, G., Evans, A., \& Hutchings, M. R. (2011). Predicting impacts of climate change on Fasciola hepatica risk. PLoS one, 6(1), e16126.

Hesterberg, U. W., Bagnall, R., Perrett, K., Horner, R., \& Gummow, B. (2008). A questionnaire survey of perceptions and preventive measures related to animal health amongst cattle owners of rural communities in KwaZulu-Natal, South Africa, Journal of the South African Veterinary Association, 78(4), 205-208.

Kagira, J., \& Kanyari, P. W. N. (2001). The role of parasitic diseases as causes of mortality in small ruminants in a highpotential farming area in central Kenya. Journal of the South African Veterinary Association, 72(3), 150-157.
Kudi, A. C., Bray, M. P., Niba, A. T., \& Kalla, D. J. (2009). Mastitis causing pathogens within the dairy cattle environment. International Journal of Biology, 1(1), 3-13.

Kumsa, B., Tadesse, T., Sari, T., Duguma, R., \& Hussen, B. (2011). Helminths of sheep and goats in Central Oromia (Ethiopia) during the dry season. Journal of Animal and Veterinary Advances,10(14),1845-1849.

Loukopoulos, P., Komnenou, A., Papadopoulos, E., \& Psychas, V. (2007). Lethal Ozolaimus megatyphlon infection in a green iguana (Iguana iguana rhinolopa). Journal of Zoo and Wildlife Medicine, 38(1), 131-134.

Ntonifor, H. N., Shei S. J., Ndale, N. W., \& Mbunkur, G. N. (2013). Epidemiological studies of parasitic infections in ruminants in Jakiri, Bui Division, North-West Region of Cameroon. Journals of Veterinary Medicine and Animal Health, 5(12), 344-352.

Nwigwe, J. O., Njoku, O. O., Odikamnoro, O. O., \& Uhuo, A. C. (2013). Comparative study of intestinal helminths and protozoa of cattle and goats in Abakaliki metropolis of Ebonyi State, Nigeria. Advances in Applied Science Research, 4(2), 223227.

Ohaeri, C. C. (2012). The parasitic helminthes of cattle slaughtered in abattoir in Umuahia South Local Government Area, Abia State, Nigeria. International Journal of Applied Research and Technology, 1(7), 85-89.

Swai, E. S., Mtui, P. F., Mbise, A. N., Kaaya, E., Sanka, P., \& Loomu, P. M. (2006). Prevalence of gastro intestinal parasite infections in Maasai cattle in Ngorongoro District, Tanzania. Livestock Research for Rural Development, 18(8), 18-27.

Tewe, O. O. (1997). Sustainability and development: Paradigms from Nigeria's Livestock Industry. Inaugural Lecture series, University of Ibadan Press, Ibadan, Nigeria.

Wang, C. R., Quu, J. H., Zhao, J. P., Xu, L. M., Yu, W. C., \& Zhu, X. Q. (2006). Prevalence of helminthes in adult dogs in Heilongjiang Province, the People's Republic of China, Parasitology Research, 99(5), 627-630.

Yuguda, A. U., Samaila, A. B., \& Panda, S. M. (2018). Gastrointestinal helminthes of slaughtered cattle in Bauchi Central Abattoir, Bauchi State, Nigeria. GSC Biological and Pharmaceutical Sciences, 4(2), 58-65. 